\title{
Study the causes of growth retardation in pure breed imported calves after theileriosis in Abu-Shaeer cattle Farm /Diyala province
}

\author{
Gh.H. Jameel \\ H. M. Majeed \\ O. J. katwan
}

Abstract

The aim of this study is investigated the causes of retardation in growth of purebred calves infected by Theileria annulata.Blood samples of infected group (treatment group) were taken once, and blood samples of the control group (clinically healthy) were taken also .Serum separation was done to two groups to determinate some blood factors levels as ferritin ,phosphorus ,glucose ,growth hormone ,total T3 and total T4.It was detected that mean values of serum Ferritin was significantly higher than the values of the control group and healthy animals.No significant effect of the infection on the phosphorus and T3 levels, While there were significant depression in serum levels of glucose, growth hormone and $\mathrm{T} 4$.

\section{Introduction}

Theileriosis is at tick -transmitted protozoan disease affecting cattle ,buffalo and sheep (1) .Theileria Spp. are obligate intracellular parasite .It is economically one of the most important and frequently fatal disease in cattle in tropical and subtropical regions of the world (2).Tropical theileriosis caused by Theileria annulata and transmitted by Hyalomma spp. ; is one of the most devastating blood parasites, morbidity and mortality considerably high(3) .Theileria annulata is progressed together with severe anemia (4) ,in addition to other clinical symptoms as prescapular and femoral lymph nodes enlargement ,high fever and anorexia (1) , and figure -1 and figure-2 is reveals the Koch blue bodies (microschizonts) inside the lymphocyte in lymph smear and, the piroplasms inside the red blood cells respectively.

Figure-1: Reveals the Koch blue bodies (microschizonts) inside the lymphocyte of infected calf. 
Figure-2:Reveals the piroplasms inside the red blood cells of infected calf.

Recovered animals are immune and do not remain carriers as do animals that have recovered from some other theileriosis (5).Plasma biochemistry may be an indication of the severity of the infection ,and a very good tool for diagnosis, prognosis and evaluation of the therapy applied. Also ,to understand the hostparasite relationship at a molecular level

\section{Materials and Methods}

The present investigation was carried out during June to November-2010 in Abu -Shaeer cattle farm in Huwaish village in Diyala province .This farm consisted two hundred imported dairy cattle and near seventy calves had been bred after 2003 incidents.

\section{The samples:}

Thirty $(5 \mathrm{ml})$ blood samples were be taken from thirty imported breed calves at age (760) days, different in sex. Twenty calves were suffered from acute theileriosis and ten clinically health considered as control group. Clinical and parasitological observation were recorded of all infected animals .Blood and lymph smears were taken, after dried had been fixed by methanol and stained by Giemsa stain(7). after (48hrs). and to describe the disease clearly, some biochemical parameters may be determined (6). The aim of the present study was to evaluate the influence of natural Theileria annulata infection in some blood components that associated with the metabolism of the imported pure breed calves.

For biochemical analysis ,serum were collected after a blood samples were allowed to clot and centrifuged at $3000 \mathrm{rpm}$ for 15 minutes, then stored in a appendroff tubes at $-20 \dot{c}$ till used (8).

\section{The medication:}

-Buparvaquone at a dose of $(2-5 \mathrm{mg}$ /Kg.Bwt.) by intramuscular injection in the muscle of the neck , and repeated

-Oxytetracycline at a dose of (20 $\mathrm{mg} / \mathrm{Kg}$.Bwt),by intramuscular injection ,and repeated after (72 hrs).

-Antipyretic drugs as metamizol at a dose of $(50 \mathrm{mg} / \mathrm{Kg}$.Bwt),by intravenous injection as a supportive treatment.

-Dextrose 5\%, by intravenous injection as a supportive treatment.

\section{Results}

Examination of the infected group prior to treatment detected anorexia ,cough, enlargement of the prescapular and femoral lymph nodes, petechial blood blisters in conjunctivas ,slight degree of anemia ,lachrymal discharge, bulgy eye ball and most the infected calves prefer to lie under sun light exposition and, figure-3 and figure-4 reveals the enlargement of femoral lymph node and bulgy eye ball of infected calf respectively. 


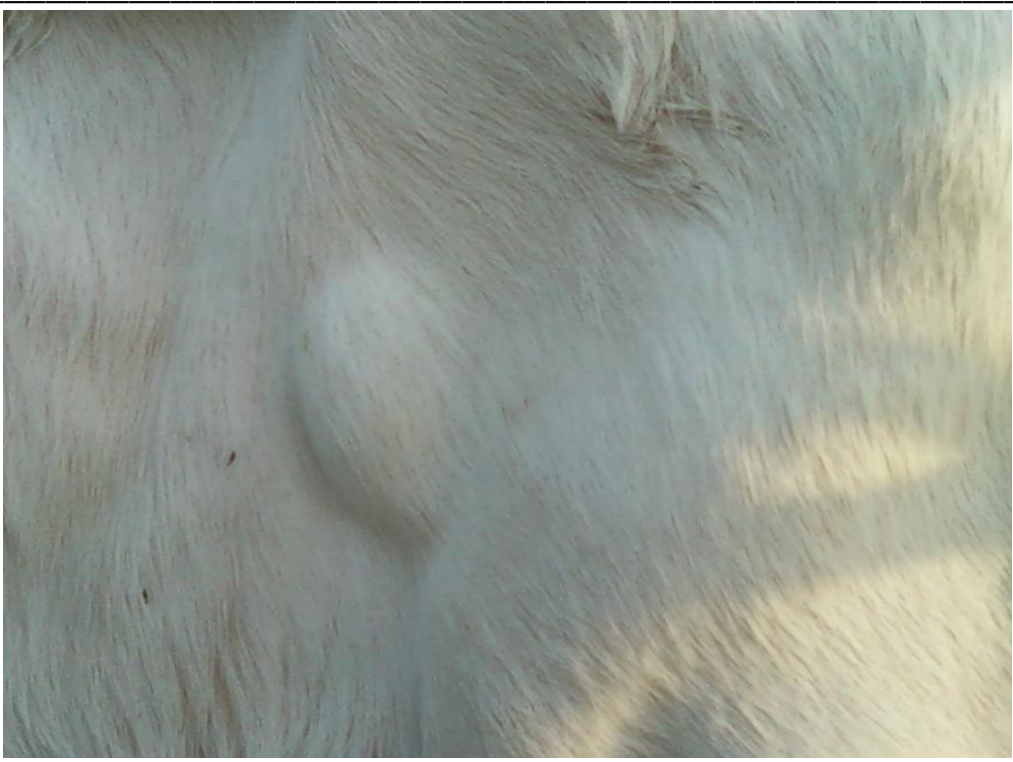

Figure-3: Reveals the enlargement of femoral lymph node of infected calf.

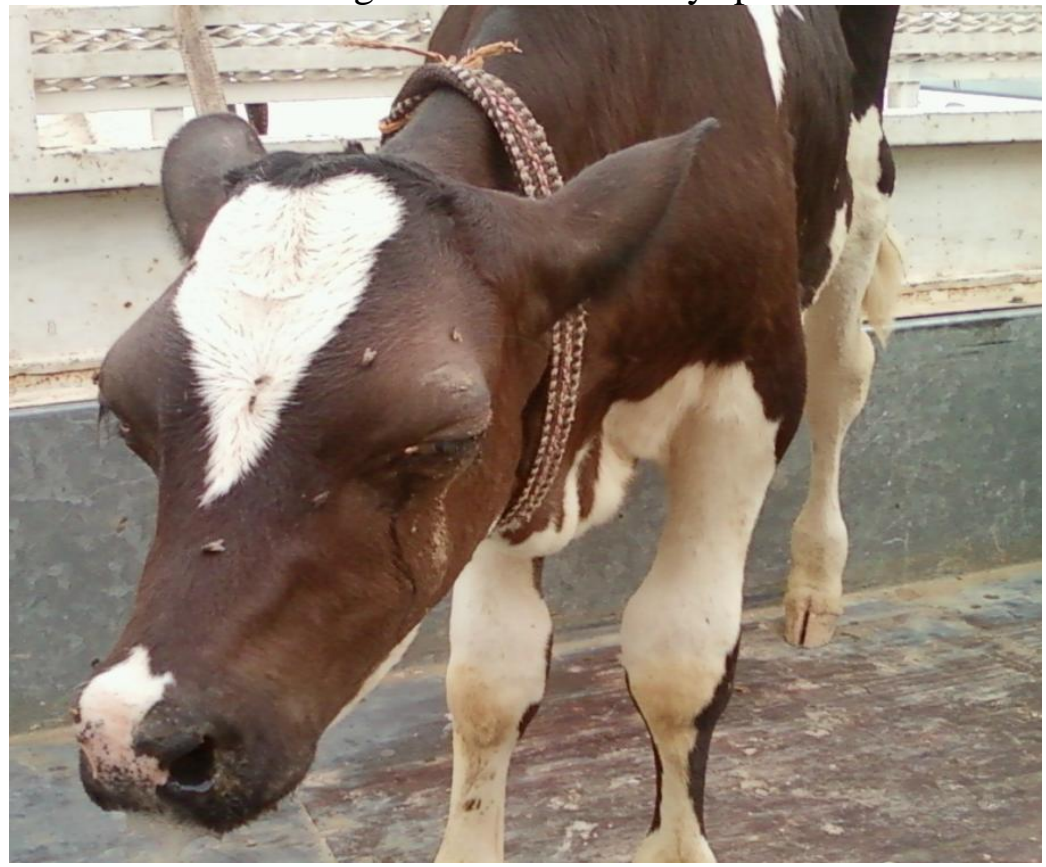

Figure-4: Reveals the bulgy eyes in calf infected by theileriosis.

Post -treatment examination showed the appetite of all the animals had returned gradually to normal .Some biochemical values of blood serum were showed in table -1 as (Ferritin, phosphorus, glucose, growth hormone ,total T3 and total T4) to elicit the influence of the differences in values between the infected animals and control group . 
Table -1: Represent the tend biochemical values in blood serum of infected and control groups.

\begin{tabular}{|c|c|c|}
\hline biochemical Values & $\begin{array}{r}\text { Treatment group mean and standard } \\
\text { deviation }\end{array}$ & $\begin{array}{r}\text { Control group mean and } \\
\text { standard deviation } \\
\end{array}$ \\
\hline ferritin & $300.089 \pm 0.805(\mathrm{ng} / \mathrm{ml}) *$ & $206.02 \pm 0.402\left(\mathrm{ng} / \mathrm{ml}^{*}\right)$ \\
\hline phosphorus & $6.740 \mathrm{I} \pm 1.508(\mathrm{Mg} / \mathrm{d} 1)$ & $5.431 \mathrm{I} \pm 0.231(\mathrm{mg} / \mathrm{d} 1)$ \\
\hline glucose & $35.50 \mathrm{I} \pm 13.273(\mathrm{Mg} / \mathrm{d} 1) *$ & $54.2 \pm \mathrm{I} 0.642(\mathrm{mg} / \mathrm{d} 1) *$ \\
\hline growth hormone & $0.440 \pm \mathrm{I} 0.670\left(\mathrm{mU} / \mathrm{ml}^{*}\right)$ & $2.4 \pm \mathrm{I} 0.33(\mathrm{mU} / \mathrm{ml})$ \\
\hline total $\mathrm{T} 3$ & $1.694 \pm \mathrm{I} 0.967(\mathrm{ng} / \mathrm{d} 1)$ & $1.78 \pm 0.121(\mathrm{ng} / \mathrm{d} 1)$ \\
\hline total T4 & $5.850 \mathrm{I} \pm 4.597(\mathrm{ng} / \mathrm{d} 1 *)$ & $4.31 \mathrm{I} \pm 1.534(\mathrm{ng} / \mathrm{d} 1) *$ \\
\hline
\end{tabular}

$(\mathrm{P}<0.05)^{*}$

\section{Discussion}

Tropical theileriosis is a protozoan disease of blood and lymph tissues .It can cause great economic losses due to the mortality rate reaching $100 \%$ as a result of severe anemia ,high fever ,anorexia ,inactivity ,decrease in efficiency, rumen movements and decrease in rumination ,respiratory distress ,paleness in mucosa and conjunctivas, petechia ,and secondary infections (9,10). Other signs ,but not noticed in all cases as blood -tinted diarrhea ,or with obvious blood clots (11).In Iraq in general and in Diyala province specially there was lack in water of irrigation resulting in decrease in amount of grass production lead to ,the owner of the farm was depend upon the grass seller market .Large numbers of ticks were be transmitted with vehicle which bring the grass from other farms and cause protozoan blood diseases as babesiosis and theileriosis. The applied therapy against theilerissis, mostly sufficient and the infected animals were gradually recovered but still suffered from slight anemia fallowed by poor growth and figure -5 reveals the recovered calf with poor growth and followed by dwarfism .These differences became clear when is compared with non infected calf in same age and breed and, figure -6 revealed the comparison.

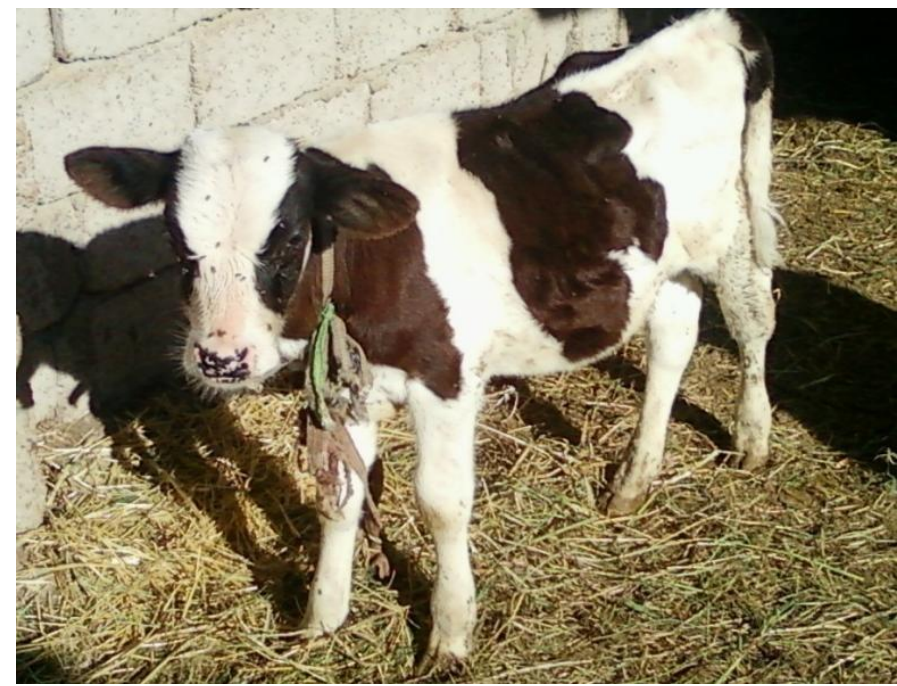

Figure -5: Represent the poor and delayed in growth of recovered calf from theileriosis. 


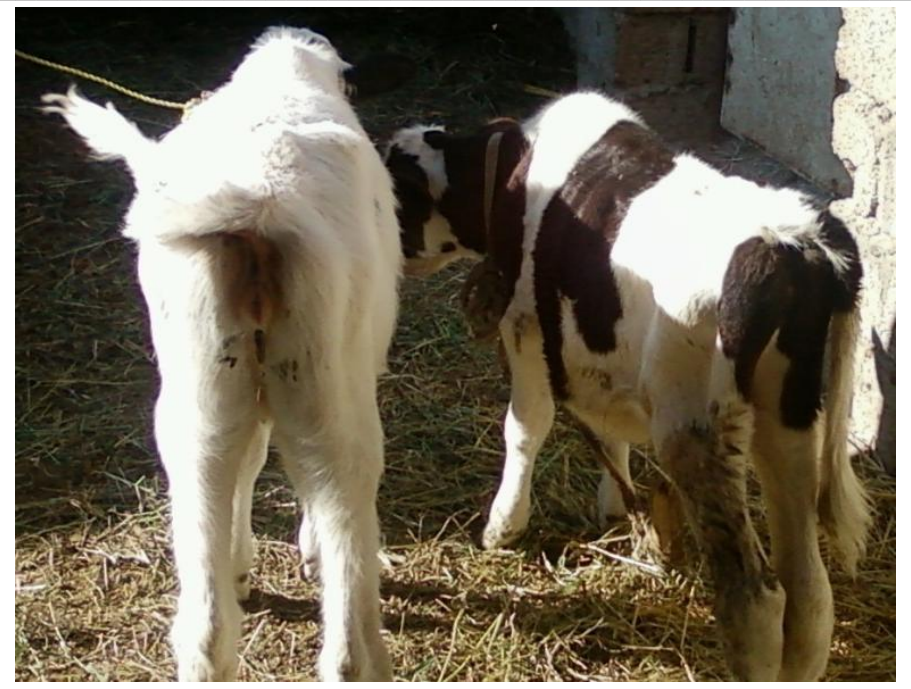

Figure -6: Represent the difference between two calves: right side is infected and, the left is non infected.

These attentions lead to our searching about the causes of retardation in growth ,also other study come in agreement with our observations and describe the disease by (a chronic wasting disease ) (12).Mean values of the serum ferritin levels were be $(300.089 \pm 0.805 \mathrm{ng} / \mathrm{ml})$ in treatment group and , $(206.02 \pm 0.402 \mathrm{ng} / \mathrm{ml})$ in control group. Statistical analysis of the serum ferritin values reveals significant elevation $\quad(\mathrm{P}<0.05) \quad$ and significant correlation with infection when is compared with the normal level in healthy animals which be $(100 \pm 6 \mathrm{ng} / \mathrm{ml})$. This result was came agreed with other study mentioned, the ferritin concentration increased drastically in the presence of an infection or cancer (13). Ferritin is a globular protein complex consisting of 24 protein subunits and is the primary intracellular iron-storage protein in both prokaryotes and eukaryotes, keeping iron in a soluble and non -toxic form , and to transport it to areas where it is required (14). In general ,the rate of iron is considered as one of some indicator of anemia or not. In fact, iron deficiency anemia remains the most common hematologic disease of infants and children(15).Mean values of serum phosphorus levels were be $(6.740 \pm 1.508$ $\mathrm{mg} / \mathrm{d} 1)$ in treatment group and
,$(5.431 \pm 0.231 \mathrm{mg} / \mathrm{d} 1)$ in control group .No statistical differences $(\mathrm{P}>0.05)$ in phosphorus levels between the two groups and also ,when they were compared with the level of healthy animals which be (3-8 $\mathrm{mg} / \mathrm{d} 1$ ). Other study was mentioned the presence of significant increase in the concentration of phosphorus in Theileria annulata infected cattle could be attributed to the hemolytic anemia caused by an immune -mediated hemolysis, resulting in an auto -immune reaction of affected erythrocytes $(16,17)$. Other study refers to significant decrease In serum phosphorus in infected animals by Theileria annulata attributed to diarrhea and renal wasting through the period of infection(18).Other study refers to significant decrease in phosphorus levels during the terminal stages of the disease (19). No difference in serum phosphorus levels of infected animals by Theileria annulata were mentioned by Hasanpour etal, study (20).Mean values of serum glucose levels were be $(35,50 \pm 13.273 \mathrm{mg} / \mathrm{d} 1)$ in treatment group and, $(54.2 \pm 0.642 \mathrm{mg} / \mathrm{d} 1)$ in control group . There is statistical difference $(\mathrm{P}<0.05)$ between the two groups when they were normal levels in health animals which be (46 mg /d1) .Other study was referred to presence of significant decrease 
in serum glucose level with Theileria annulata infection (18), and come with our study agreed.We applied the glucose therapy to reach the glucose inside the body cells and stimulate the energy production later because, the liver had been infected and become enable to maintain blood sugar in normal level. Also other studies were prescribe $5 \%$ dextrose as supportive treatment $(9,21)$. Mean value of growth hormone levels were be $(0.440 \pm$ $0.670 \mathrm{mU} / \mathrm{ml})$ in treatment group, and $(2.4$ $\pm 0.33 \mathrm{mU} / \mathrm{ml}$ ) in control group. There were significant depression in growth hormone levels $(\mathrm{p}<0.05)$ in treatment group when it compared with control group and healthy animals which be (less than 3 $\mathrm{mU} / \mathrm{ml}$ ). Growth hormone is secreted throughout life .It is the single most important hormone for normal growth to adult stature. The major factors that alter growth hormone secretion are hypoglycemia (a decrease in blood glucose concentration) and starvation .It is secreted from anterior lobe of pituitary gland. The actions of growth hormone include effects on linear growth, protein synthesis and organ growth ,carbohydrate metabolism , and lipid metabolism .Growth hormone deficiency in children results in failure to grow ,short stature ,mild obesity ,and delayed puberty (22). Animals with growth hormone lack elicit dwarf look because the delay in growth may be due to the depression in thyroid gland activity same as the body tissues or organs growth retardation and the calf in figure -5 above represents this state .No similar study was found and refers to the effect of Theileria annulata infection on growth hormone secretion. Mean values of total triiodothyronine (T3) levels were be $(1.694 \pm 0.967 \mathrm{ng} / \mathrm{d} 1)$ in treatment group and,$(1.78 \pm 0.121 \mathrm{ng} / \mathrm{d} 1)$ in control group .Mean values of total thyroxin (T4) were be $(5.850 \pm 4.597 \mathrm{ng} / \mathrm{d} 1)$ in treatment group and , (4.31 $\pm 1.534 \mathrm{ng} / \mathrm{d} 1)$ in control group .There is no significant correlation $(\mathrm{P}>0.05)$ in serum T3 levels in treatment and control group when they compared with serum T3 level of healthy animals which be (1-2.2 $\mathrm{ng} / \mathrm{d} 1)$. While there is significant depression $(\mathrm{P}<0.05)$ in serum $\mathrm{T} 4$ levels in treatment and control groups when is compared with serum T4 level in healthy animals which be $(7.2-14.4 \mathrm{ng} / \mathrm{d} 1)$.This depression in $\mathrm{T} 4$ levels is affect the synthesis of T3 .Study was refer to hormonal output of the thyroid gland is $\mathrm{T} 4$ then ,T4 is solved by the target tissues ,which convert up to $80 \%$ of the $\mathrm{T} 4$ to T3.Also was refer to activity of T3 than T4 (23).Analysis of tend values of serum growth hormone levels, T3 and T4 levels after Theileria annulata infection reveals the presence of relationship with retardation in growth ,because of the thyroid hormones in addition to the effect of growth hormone, have effects on virtually every organ system in the body, including those involved in normal growth and development (22). T3 and T4 are synthesized from both iodine and tyrosine. In areas of the world where iodine is lacking in the diet resulting in problem of physical growth (a condition referred to as endemic cretinism ) due to lack in $\mathrm{T} 3$ and T4 synthesization (24).Several studies were investigate the serum T3 and T4 levels after Theileria annulata infection as the study was done by Issi etal. which founds significant depression in total T3 and T4 when they compared with total T3 and T4 of control animals (25). Also three studies were recorded the significant decrease in serum $\mathrm{T} 3$ and $\mathrm{T} 4$ levels in tropical theileriosis $(26, \quad 27 \quad 28) \quad$.Our recommendation to prevent the complications after theileriosis ,early treatment of infected animals with blood parasites diseases and supportive treatment . Also application of ticks eradication program . And periodical examination of iodine levels in animal food stuffs. 


\section{References}

1-Radostictis O.M, C.C Gay, D.C. Blood and K.W. Hinehcliff. 2000.A Text book of the Disease of cattle, sheep, pigs ,goats and horses .(9th)ed. ,press. Harcourt publisher Ltd-pp:1059-1066.

2.Guzel M. ,T.K. Askar ,G. Kaya ,E Atakisi and G.Avci.2008. serum sialic acids ,total antioxidant capacity and adenosine deaminase activity in cattle with theileriosis and anaplasmosis. Bull. Vet .Inst. pulawy 52:227-230.

3.Hasanpour A., G.A. Moghaddam and A. nematollahi.2008. biochemical, hematological and electrocardiographic changes in buffaloes naturally infected with Theileria annulata. Korean J. parasitol; 46(4):223- 227.

4.Saber A.P .R .,M .Khorrami and M. Nouri .2008.Evaluation of hematological parameters in crossbred cattle naturally infected with Theileria annulata in Iran. Int. J. dairy Sci., 4: 205-209.

5.Siegmund O.H., C.M. Fraser, J. Archibald , D.C. Blood, J.A. Henderson, G.H. Snoeyenbos and W.L.Weipers.1979. East coast fever. The Merck Veterinary Manual.(5th)ed.U.S.A.p:340-432.

6.Col R. and U. Uslu .2007. Changes in selected serum components in cattle naturally infected with Theileria annulata .Bull. Vet .Inst. pulawy, 51: 15-18. 7.Feldman B.F., J.G. Zinki and n.c. Jain .2000.Schalms $\square \quad$ Veterinary Hematology ,(5 th)ed. Philadelphia, Lippincott, Williams, and Wilkin.

8.Coles E.H. 1974 .Veterinary Clinical Pathology .(2 nd)ed. W.B .Saunders company, Philadelphia USA.
9.Altug N. ,N. Yuksel, Z.T. Agaoglu and I.Keles.2008.Determination of adenosine deaminase activity in cattle naturally infected with Theileria annulata. Trop.Anim.Health.prod,40 : 449 456.

10.Omer O.H., K.H.E1. Malik ,O.M .Mahmoud, E.M. Haroun, A. Hawas, D. Sweeney and M. Magzoub .2002.Haematological profiles in pure bred cattle naturally infected with Theileria annulata in Saudi Arabia. Vet. Parasitol., 107: 161-168.

11.Mahin L.2010 . Tropical theileriosis. Lucien mahins $\square$ web-page on his clinical experience with Theileria annulata disease. Wikimedia Foundation ,Inc., a non-profit organization.

12.Siegel S., E. Howerth and B.E. LeRoy. 2006.East coast Fever (Theileria parva)-A Review. W.W.W. vet. uga. edu/ vpp/CLERK/ siegel /index .php.

13.Ong D., L. wang, Y. zhu, B. Ho and J. Ding .2005.'The response of ferritin to LPS and acute phase of Pseudomonas infection" Journal of endotoxin research 11(5): 267-280.

14.Seckback J.1982.'Ferreting out the secrets of plant ferritin- A review." Journal of plant Nutrition 5:369-394.

15. Booth I.W and M. A. Aukett. 1997 .Iron deficiency anemia in infancy and early childhood. Arch Dis child; 76: 549-554.

16. Hooshmand -Rad. P. 1976 .The pathogenesis of anemia in Theileria annulata infection .Res. Vet. Sci., 20:324.329.

17. Jain N.C. 1993. Essentials of veterinary Hematology. Ist Edn; Lea and Febiger publication, Philadelphia, PP:589-595. 
18. Col R. and UsIu U.2007. changes in selected serum components in cattle naturally infected with Theileria annulata. Bull vet Inst Pulawy 51, 15-18.

19.Sandhu G.S., A.S. Grewal, A. Singh, J.K. Kondal , J. Singh and R.S. Brar. 1998.Haematological and biochemical studies on experimental Theileria annulata infection in crossbred calves. Veterinary Research communications volume 22,(5): 347-354.

20. Hasanpour A.,G.A. Moghaddam and A. nemato llahi.2008.Biochemical, Hematological and Electrocardiographic changes in Buffaloes Naturally infected with Theileria annulata. Korean J Parasitol. Vol. 46,No-(4):223-227.

21. Keles I., S. Deger, N. Altug, M .Karaca and C.Akdemir. 2001.

Tick-borne disease in cattle: Clinical and Hematological findings, diagnosis , treatment, seasonal distribution, breed, Sex and age. Factors and the transmitters of the diseases .YYU .Vet .Fak. Derg ., 12:26-32.

22.Costanzo L.S.2004. Regulation of Growth Hormone secretion. Physiology. (2 nd) ed. P:363364.Saunders An Imprint of Elsevier.

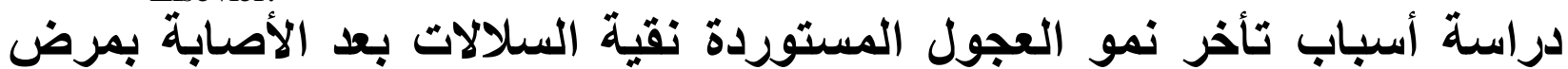

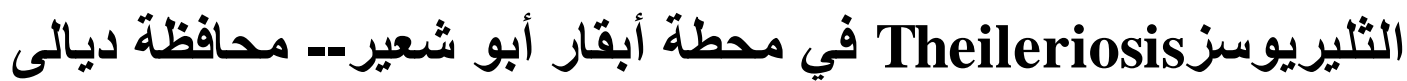

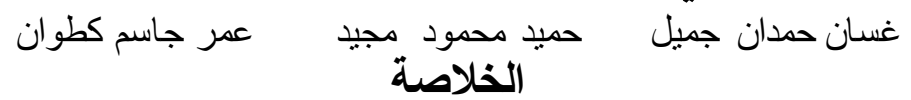

تهذف الدراسة الى التقصي عن أسباب تأخر نمو ألعجول نقية السلالات المصابة بمرض التلتيريوسز.تم أخذ عينات من

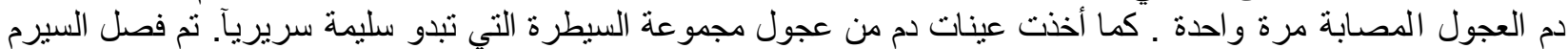

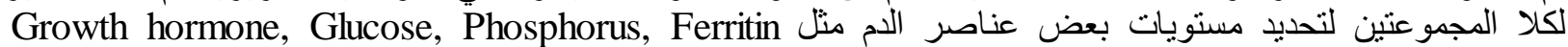

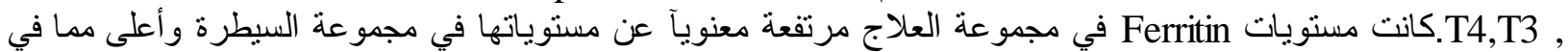

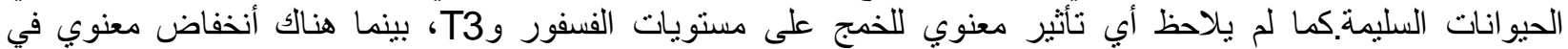
مستويات الكلوكوز وهرمون النمو وT4. 